\title{
A Dynamic Gradient Ratio Test Apparatus
}

\author{
M. W. Khan ${ }^{1}$, A. R. Dawson², A. M. Marshall ${ }^{3}$
}

$1 \mathrm{PhD}$, Department of Civil Engineering, Faculty of Engineering, The University of Nottingham, University Park, Nottingham, United Kingdom, Email: khan.mw@outlook.com

2 Associate Professor, Department of Civil Engineering, Faculty of Engineering, The University of Nottingham, University Park, Nottingham, United Kingdom, Email: andrew.dawson@nottingham.ac.uk

3 Associate Professor, Department of Civil Engineering, Faculty of Engineering, The University of Nottingham, University Park, Nottingham, United Kingdom, Email: alec.marshall@nottingham.ac.uk

\begin{abstract}
The soil-geotextile filtration mechanism is a complex process which depends on physical compatibility between the geotextile and the soil to be retained. Several methods have been proposed by researchers for assessing the filtration behaviour of soil-geotextile composite systems under steady state conditions. The Gradient Ratio (GR) test is the most commonly used method for measuring filtration compatibility of soil-geotextile systems. This paper describes the design of a modified GR permeability test apparatus to overcome disadvantages associated with traditional GR test devices. The apparatus can perform filtration tests under static and dynamic conditions and can be used to evaluate the filtration compatibility of fine-grained soils with geotextiles. The apparatus is incorporated within a triaxial testing system, hence representative field stress conditions can be applied to test specimens. Some exemplar GR tests performed on coarse and fine-grained soils with a non-woven geotextile are presented in this paper. Unidirectional dynamic loads are applied within the filtration tests to replicate highway traffic loading. Test results show that dynamic loading affects the filtration behaviour at the soil-geotextile interface by increasing the fine particles migration towards the geotextile, but that, for the soil evaluated here, this effect was small.
\end{abstract}

\section{KEYWORDS}

Geosynthetics, soil/ geotextile system, gradient ratio test, filtration, dynamic conditions

\section{INTRODUCTION}

Filters are frequently used in civil engineering to permit drainage of water from soils or waste materials. A filter should retain a range of particle sizes to avoid erosion of the contained material while allowing water to move freely through the filter, thereby preventing the development of excess pore water pressures (Moraci and Mandaglio, 2008). A traditional filtering technique in many civil engineering constructions (e.g. retaining walls, roadways, earth dams or bank revetments) involves the use of graded granular materials (i.e. gravels and sands). In the last few decades, geosynthetics (i.e. geotextiles) have begun to replace graded granular filters due to their cost and space saving advantages, as well as the versatility achieved through variations in fabric design/manufacture (Giroud, 1996). The geotextile market is projected to reach \$USD 8.18 Billion by 2024, growing at a mean annual growth rate of $10.4 \%$ from 2016 to 2024 (Grand View Research, 2016). 
The most common use of geotextiles in highways and railways is as a separator layer to stop mixing of sub-grade particles with the base-soil/sub-ballast layer. While performing as a separator, geotextiles also act as a filter which allows water to flow from the subgrade into the sub-base/sub-ballast layer. Geotextiles are also used as filters around trench drains and edge drains to stop erosion of subgrade soils into the drainage aggregate.

The filtration mechanism at the soil-geotextile interface is a complex process. A geotextile should retain soil particles without causing excessive clogging inside the geotextile openings. The blocking of drainage paths inside geotextiles results in a decrease in drainage capacity of the filtering system (Giroud, 1996, Palmeira and Trejos, 2017), which may result in pressure build-up and instability issues (Moraci, 2010).

Geotextiles may be subjected to steady or dynamic conditions. Steady flow can generally be considered as a less severe condition compared to flow under dynamic, cyclic or pulsating loads (Carroll, 1983). Under static flow conditions, the soil next to geotextile tends to form a bridging network which prevents the passage of other soil particles and eventually leads to a stabilized flow. Dynamic conditions exist in a variety of scenarios, for example under bank revetments due to hydraulic disturbance, or under roads and railways due to mechanical disturbance (Hameiri, 2000). Dynamic conditions may impair the formation of the bridging network, causing the pumping of particles that are smaller than the filter opening size. The Gradient Ratio (GR) test is the most commonly used method for measuring filtration compatibility of soil-geotextile systems (ASTM D5101); but its applicability is generally limited to static conditions.

The ability of geotextiles to enhance the performance of pavements and railroad tracks in terms of reducing permanent surface deformation has been studied by many researchers (e.g. Indraratna and Nimbalkar, 2013, Arulrajah et al., 2015, Chen et al., 2017). However, very little literature is available about the dynamic filtration performance of geotextiles in highways and railways. Experimental work has been carried out to observe the pumping of fines from subgrade to sub-base/subballast layers through a geotextile separator (Bell et al., 1982; Hoare, 1982; Alobaidi and Hoare, 1996, Fatahi et al., 2011). The principle of these tests is shown in Fig. 1. The test determines the migration of fines by measuring the particle size distribution of the sub-base/subballast layer before and after the test. Unfortunately, these tests provide no measurement of the excess pore water pressure at the soil-subgrade interface, which would provide information regarding the degree of clogging of the geotextile (discussed in detail below). Hammeri (2000) and Fannin and Pishe (2001) modified traditional GR test equipment (see Fig. 2) to perform cyclic tests. The traditional GR test equipment uses a rigid wall permeameter, which has limitations related to side wall leakage and limited control over stresses (Harney \& Holtz, 2001; Lee \& Bourdeau, 2006). Kermani et al. (2018) studied pumping of subgrade fines into the subbase of a flexible pavement using a rigid steel container. They concluded that geotextiles are effective in reducing migration of subgrade fines into the subbase layer.

The aim of this paper is to describe the development of a new dynamic GR test apparatus designed to overcome the various limitations of existing static and dynamic GR tests methods. Furthermore, the aim is to demonstrate it suitability for gaining insight into the factors governing the performance of geotextile filters under realistic cyclic loading conditions typical of roadways. The proposed dynamic GR test 
(1) measures pore pressures at the soil-geotextile interface during cyclic loading (enabling quantification of geotextile clogging),

(2) incorporates a flexible membrane to allow control of the confining pressure applied to the sample and prevent sidewall leakage, and

(3) applies static or cyclic loads that are characteristic of a roadway environment.

This paper begins with a description of existing GR test devices and outlines their limitations. A description of the design and testing of the new dynamic GR test apparatus is then provided and experimental data are presented and analysed from two tests on two soil-filter combinations. Key outcomes from the tests are presented and discussed.

\section{GRADIENT RATIO TESTS}

Several methods have been proposed for assessing the filtration behaviour of soilgeotextile composite systems under steady state conditions. These include the long-term flow test (Rollin and Lombard, 1988; Aydilek and Edil, 2003; Kutay and Aydilek, 2005; Veylon et al., 2016), hydraulic conductivity ratio test (Williams and Abouzakhm, 1989; Shan et al., 2001; ASTM D5567), and the Gradient Ratio (GR) test (Haliburton and Wood, 1982; Fannin et al., 1994; Fischer et al., 1999; Palmeira et al., 2005; Lee and Bourdeau, 2006, Hong and Wu, 2011). Among these test methods, the GR test is the most commonly used filtration test and is also the standard test method for measuring filtration compatibility of soil-geotextile systems (ASTM D5101). The GR test apparatus conventionally used here comprises a rigid wall permeameter which accommodates a cylindrical sample of $100 \mathrm{~mm}$ length and diameter placed on a geotextile (Fig. 2). The energy dissipator mounted below the inlet prevents the top of the soil, below the inlet, from being disturbed when the flow rates are high. Hydraulic head is deduced from pore pressure measurements obtained using piezometers installed at various positions down the wall of the permeameter. A GR is the ratio of hydraulic gradient across the soil geotextile interface $\left(i_{\mathrm{sg}}\right)$ compared to the hydraulic gradient within the soil $\left(i_{\mathrm{s}}\right)$. The GR, with reference to manometer port locations 3, 5 and 7 (see Fig. 2), can be defined as:

$$
\mathrm{GR}=\frac{\left(\mathrm{h}_{57} / \mathrm{L}_{\mathrm{sf}}\right)}{\left(\mathrm{h}_{35} / \mathrm{L}_{\mathrm{s}}\right)}
$$

where $h_{57}$ and $h_{35}$ are water head across the soil-geotextile interface (between Ports 5 and 7) and within the soil (between Ports 3 and 5), respectively, $L_{s}$ is the distance between port 3 and port 5 , and $\mathrm{L}_{\mathrm{sf}}$ is the distance between port 5 and the support screen.

A value of GR $\leq 1$ is preferred for use of geotextiles in filtration applications (Holtz et al., 2008). GR = 1 suggests that the geotextile has not influenced the flow through the system, whereas GR $<1$ indicates that fine particles have passed through the filter and a more open filter bridge has formed at the soil-filter interface. A continuous decrease in GR with time (below 1) indicates piping. GR values greater than 1 indicate that the geotextile, or the soil-geotextile boundary, has been clogged by the soil particles, resulting in a reduction of flow at the soil-filter interface. The U.S. Army Corps of Engineers (1977) indicates that a soil-geotextile system with GR values greater than 3 is unacceptable.

The GR test has various limitations. The piezometer ports at the perimeter of the permeameter could affect sample preparation and pore pressure readings (Chang et al., 2004). The conditions in a typical GR test apparatus are limited to low confining stresses 
representative of shallow depths. There is also the possibility of leakage along the rigid wall of the permeameter, which can affect the evaluation of hydraulic gradient and effective stress within samples. The potential for sidewall leakage in a rigid wall permeameter can be reduced (e.g. using piping barriers as suggested in ASTM D5101), however it cannot be completely eliminated (Mohamed and Paleologos, 2017). Moreover, due to the lack of back pressure saturation, the GR test is not recommended for fine grained soils (Holtz et al., 2008). ASTM D5101 urges the use of $\mathrm{CO}_{2}$ gas through the permeameter to remove air from soil samples prior to water saturation. Even so, full saturation of the soil samples cannot be verified. Some of these limitations can be addressed by using a flexible wall gradient ratio (FWGR) test apparatus (Harney and Holtz, 2001, Bailey et al., 2008) in which fine-grained soils can be fully saturated by applying back saturation. The FWGR test is a combination of features of a flexible wall permeability test (ASTM D5084) and the standard GR test. The flexible wall permeameter can eliminate sidewall leakage since the flexible membrane is in full contact with soil (Mohamed and Paleologos, 2017).

The test conditions in a traditional GR test are static and unidirectional. Hameiri (2000) suggested a GR apparatus that is able to measure pore water pressures within the soil and across the soil-geotextile interface for the study of dynamic loading conditions beneath highways. The apparatus allows good control over applied stresses, however it used piezometers which were not able to effectively measure excess pore pressures during the dynamic loading process; the test was only able to characterize sample before and after the application of loads. The test also adopted a rigid wall design, with associated issues related to leakage. A good control of stress conditions in the rigid wall test was achieved by an automatic controlled vibration system.

\section{DYNAMIC GR APPARATUS}

Fig. 3 shows a diagram of the newly developed dynamic GR test apparatus. The dynamic GR apparatus includes; use of a modified triaxial cell with the sample placed within a flexible membrane (instead of rigid wall permeameter), pore pressure transducers instead of piezometer tubes, application of confining pressure using compressed air, application of hydraulic gradient across the system by adjusting the heights of the top and bottom reservoir tanks, and application of cyclic loading using an INSTRON machine.

\subsection{MODIFIED TRIAXIAL CELL}

The modified triaxial cell is shown in Fig. 4 (a). A $0.64 \mathrm{~mm}$ thick rubber latex membrane, which acts as a flexible wall, was used to hold the soil sample and geotextile. The triaxial cell can accommodate a sample of $50 \mathrm{~mm}$ diameter and $100 \mathrm{~mm}$ height, giving a height to diameter ratio of 2 . The authors designed and constructed a unique bottom pedestal (Fig. 4 (c)) of $50 \mathrm{~mm}$ diameter capable of collecting any soil particles passing through the geotextile. Grooves, $5 \mathrm{~mm}$ in depth, were machined into the pedestal to convey soil particles to a bottom reservoir tank. A total of 4 ports were required for two differential pressure transducers (DPTs - details provided later). One DPT measured the pressure difference within the soil from $25-75 \mathrm{~mm}\left(\mathrm{~h}_{25-75}\right)$ above the geotextile, while the other measured the pressure difference across the geotextile $\left(\mathrm{h}_{\mathrm{g}-25}\right)$. 


\subsection{LOADING AND HYDRAULIC SYSTEM}

An INSTRON machine with a servo-controlled hydraulic actuator capable of applying a vertical load of $100 \mathrm{kN}$ was used to induce cyclic loading. The INSTRON loading frame was connected to an oil hydraulic system controlled by PC Rubicon software via a switchbox. Cyclic loading conditions and the number of loads were selected using the Rubicon software. Repeated cyclic load on test samples was generated by the dynamic actuator within the INSTRON test cylinder. The constant head difference on test samples was applied using two water tanks, i.e. a Mariotte bottle and a bottom tank (Fig. 3).

The Mariotte bottle (top right part of Fig. 3) is a device which delivers liquid at a constant pressure. The bottle has two openings: one at its top for an air inlet tube and the other at the bottom for a water outlet tube. The pressure at the bottom of the air inlet remains the same as outside the bottle i.e. it is at atmospheric pressure. As long as the water level in the bottle is above the bottom of the air inlet pipe, the water at that level will remain at atmospheric pressure (regardless of the level or volume of the water in the vessel) and the device will supply water at a constant pressure.

The required confining pressure was applied to the sample by compressed air and regulator valves. A 5mm PVC hose pipe connected the air pressure valve to the triaxial cell. A $5 \mathrm{kPa}$ pressure gauge was fixed at the top of the triaxial cell to monitor the pressure inside the triaxial cell. The compressibility of air allowed easy movement of the axial piston; fluctuation of pressures due to piston entry and exit from the cell was negligible. Soil particles passing through the geotextile were collected in the bottom reservoir (Fig. $3)$. After each test, water from the bottom tank was passed through wet strength filter paper (pore size $0.002 \mathrm{~mm}$ ) to collect the soil particles. The dry weight of the filter paper and soil particles was measured to determine the weight of soil particles lost from the soil. A graduated cylinder connected to the overflow of the bottom reservoir tank was used to measure the rate of discharge. The coefficient of permeability of soil $\left(\mathrm{k}_{\mathrm{s}}\right)$ and across the soil-geotextile interface $\left(\mathrm{k}_{\mathrm{sg}}\right)$ were calculated using the system flow rate and the head difference that occurred within soil sample $\left(\mathrm{h}_{25-75}\right)$ and across soil-geotextile interface $\left(\mathrm{h}_{\mathrm{g}}\right.$ 25), respectively, using Darcy's law:

$\mathrm{Q}=\mathrm{kA} \frac{\Delta \mathrm{h}}{\mathrm{L}}$

where $\mathrm{Q}$ is the total discharge $\left(\mathrm{m}^{3} / \mathrm{s}\right)$, $\mathrm{k}$ is coefficient of permeability $(\mathrm{m} / \mathrm{s})$, A is crosssectional area of the test sample $\left(\mathrm{m}^{2}\right), \Delta \mathrm{h}$ is difference in head $(\mathrm{m})$, and $\mathrm{L}$ is length $(\mathrm{m})$.

\subsection{PRESSURE TRANSDUCERS}

Ports were fabricated in the membrane to connect allow tubes to pass from the soil to the DPTs (see Fig. 4d). 5mm inner diameter (ID) plastic tubes were extended $25 \mathrm{~mm}$ into the centre of the $50 \mathrm{~mm}$ diameter samples. Porous filters were inserted into the tips of the plastic tubes to prevent blockage with soil. The plastic tubes were fixed to the membrane using $5 \mathrm{~mm}$ nuts bonded to the inner and outer sides of the membrane. The nuts ensured that the plastic tubes were horizontal and helped eliminate leakage at the ports. The ports of the DPTs required $1.5 \mathrm{~mm}$ OD pipes, hence a coupler was fashioned at the ports to step down to $1.5 \mathrm{~mm}$ from the $5 \mathrm{~mm}$ ID pipe (all gaps around the pipes and nuts were sealed with silicone). The port below the geotextile specimen was connected by drilling a $5 \mathrm{~mm}$ 
diameter threaded hole in the bottom pedestal such that it intersected the water channel connected to the outlet valve (labelled as X in Fig. 4(a)).

The DPTs (Honeywell 24PCBFA6D pressure sensor) have 0 to $34 \mathrm{kPa}$ range and a response time of 1 millisecond (Fig. 4b). The DPTs have two ports with a pressure sensing element between them and a connection size of $1.5 \mathrm{~mm}$. One pore pressure transducer (PPT) was also connected at the outlet valve of the triaxial cell to provide a datum from which the differential pressures, measured by the DPTs, could be converted to absolute pore pressures. The PPT readings allowed computation of the total water head at $25 \mathrm{~mm}$ and $75 \mathrm{~mm}$ above the geotextile (since the DPTs only give differential pressure readings). The pressure transducers were connected to an HBM Spider 8 data logger and CATMAN software was used to record the output voltages. All pressure transducers were calibrated prior to each test to obtain accurate conversion factors of voltage output to pore water pressure readings. The DPTs were calibrated by connecting the ports to two water tanks with known and variable water elevations. The PPT was very well saturated and calibrated with the use of a dedicated apparatus, described in detail by Matziaris et al. (2015).

\section{TEST MATERIALS}

Two soils and one geotextile were selected for filtration tests to commission the dynamic GR apparatus. The geotextile was a needle-punched and thermally bonded non-woven fabric. The geotextile was selected due to its frequent use as a filter for applications such as pavement edge drains, reservoirs and dams, and under revetments. The physical properties of the geotextile were provided by the manufacturer. The equivalent opening size (EOS or $\mathrm{O}_{90}$ ) of the geotextile was $0.070 \mathrm{~mm}$ (BS EN ISO 12956) which means that $90 \%$ of the pores within the geotextile are smaller than $0.070 \mathrm{~mm}$. The geotextile had a mass/area of $294 \mathrm{~g} / \mathrm{m}^{2}$ and a thickness of $1.7 \mathrm{~mm}$. The permeability of the geotextile was reported as $65 \times 10^{-3} \mathrm{~m} / \mathrm{s}$.

The tests used two cohesionless soils: sand and pulverized fuel ash (PFA). The gradation curves of the soils are shown in Fig. 5. The sand can be classified as medium sand according to British Standard 5930 (2015). PFA is a fine material with most particles in the silt range. The PFA sample is broadly graded and has a concave upward gradation (Fig. 5), indicative of an internally unstable soil (Lafleur et al., 1989, Moraci et al., 2012) where fine particles can move easily within the coarse particles. The formation of a bridge network is not expected in such soils (this occurs when the coarse particles are stopped at the filter interface and they, in turn, prevent fine particle migration from forming an auto - filtration layer).

Fig. 5 shows that the nearly all of the sand particles are larger than the $\mathrm{O}_{90}$ of the geotextile, while $90 \%$ of the PFA particles are smaller than O90. The sand and PFA soils were selected to test clogging of geotextile pores and piping of particles through the geotextile pores, respectively. The physical properties of sand and PFA are given in Table 1. 


\section{SPECIMEN PREPARATION}

The specimen preparation for each test involved the following. A rubber membrane was sealed to the bottom pedestal of the triaxial cell with a rubber o-ring. A steel mould was then clamped around the rubber membrane and the membrane was stretched around the mould. A 50mm diameter cuspated core was then placed on the pedestal, inside the rubber membrane (Fig. 4a). The purpose of cuspated core was to provide a supporting frame for the geotextile, while allowing water to pass through it. The geotextile sample for each test was cut slightly bigger than the diameter of the rubber membrane to prevent flow around the edges of the geotextile. The geotextile sample was placed in a bath of de-aired water and squeezed manually to ensure that no air was trapped inside the pores. To simulate field conditions, soil samples were prepared inside the rubber membrane at maximum dry density. Soils were compacted in four layers of $25 \mathrm{~mm}$ depth. All soil samples were compacted to between 90 and $95 \%$ of the maximum dry density. After compacting the last layer of soil, the pre-saturated porous stone and top pedestal were carefully placed on top of the soil sample. The rubber membrane was rolled up around the top pedestal and sealed with an o-ring. The pipes from the rubber membrane and below the geotextile were connected to the DPTs and the PPT was fixed to the connection block. The specimen was saturated using a back pressure of $20 \mathrm{kPa}$, supplied via the Mariotte bottle. The Mariotte bottle was first connected to the outlet valve of the triaxial cell, keeping both inlet and outlet valves closed. Compressed air was then connected to the triaxial cell, applying a confining pressure of $30 \mathrm{kPa}$. Both inlet and outlet valves were then opened, allowing water to flow through the specimen from bottom to top. After sample saturation, the back pressure line was connected to the inlet valve and the specimen was left overnight to achieve a satisfactory level of saturation. Skempton's $B$ values $\left(B=\Delta u / \Delta \sigma_{3}\right)$ of between 0.8 and 0.9 were obtained for all tests; Black and Lee (1973) showed that a B value ranging between 0.8 and 0.9 for less compressible soils indicates a degree of saturation of more than $99 \%$.

\section{TEST PROCEDURE}

The filtration behaviour of the soil-geotextile interfaces was examined by performing stages of static and cyclic loading. A very low confining pressure $\left(\sigma_{3}\right)$ of $20 \mathrm{kPa}$ was applied in all tests simulative of static ground stresses anticipated in a highway application. The tests were carried out under a hydraulic gradient $(\Delta \mathrm{h} / \mathrm{L})$ of 5 (see Eq. 1 ) which was controlled by adjusting the heights of the Mariotte bottle and bottom tank. A hydraulic gradient of $\leq 1$ is expected in pavement edge drains (Giroud, 2010). However, a hydraulic gradient as high as 5 is possible in realistic field conditions, for example, if partial leakage is allowed through a pavement boundary (Lee and Bourdeau, 2006).

During static flow, no vertical load was applied $\left(\sigma_{1}=0\right)$ and the filtration behaviour of the soil-geotextile specimens was observed. The test was run for one to two hours until constant readings of pore pressure and flow rate were obtained. Unidirectional cyclic loading was then applied at a frequency of $1 \mathrm{~Hz}$ (concurrent with flow), which is within the typical traffic load frequency range of 0-10 Hz (Hyde et al., 1993). During the cyclic stage, a deviator stress $\left(\mathrm{q}=\sigma_{1}-\sigma_{3}\right)$ of $30 \mathrm{kPa}$ was applied. This deviator stress is applicable to a typical pavement thickness of $450 \mathrm{~mm}$, as calculated using KENLAYER (Huang, 1993), a pavement/design analysis software based on an elastic multilayer system under a circular loaded area. An axle equipped with single tyres having a standard axle load of 
$80 \mathrm{kN}$ was considered in the analysis. A commonly used tire pressure of $700 \mathrm{kPa}$ and tire radius of $150 \mathrm{~mm}$ were used in the analysis. All the tests were run for 5000-10000 cycles depending on the stability of the pore pressure and flow rate readings. The amount of soil particles passing through the geotextiles (collected in the lower reservoir) were then measured.

\section{RESULTS AND DISCUSSION}

The water head distribution and the permeability values for the static and cyclic stages of Test 1 on sand (see Table 1) are reported in Fig.6. Fig. 6 (a) shows that the magnitude of water head for both static and cyclic stages is less than the reference or theoretical water head distribution for a hydraulic gradient of 5. This is probably due to high flow rates in the system $\left(0.003-0.008 \mathrm{~m}^{3} / \mathrm{s}\right)$, which may cause head losses elsewhere in the system (such as pipe fittings) to become significant and disproportional to those in the soil and geotextile. The same effect was measured by Hameiri (2000) and Hawley (2001) who found that the total head loss across the samples decreased when the flow rate increased.

It can be seen from Fig. 6 (a) that, during the static stage, the hydraulic gradient or rate of head loss across the soil-geotextile interface $\left(\mathrm{h}_{\mathrm{g}-25}\right.$ per $\left.\mathrm{mm}\right)$ is more than the rate of head loss within the soil ( $\mathrm{h}_{25-75}$ per $\mathrm{mm}$ ) after 100s, giving an initial GR of approximately 1.25. Fig. 6 (b) shows coefficient of permeability (k). Based on the volume of water collected and water head measurements (Eq. 1), the value of $\mathrm{k}$ was estimated to a resolution of $1 \mathrm{x}$ $10^{-6} \mathrm{~m} / \mathrm{s}$ for Test 1 . Fig. 6 (b) shows that the permeability across the geotextile $\left(\mathrm{k}_{\mathrm{sg}}\right)$ is less than within the soil $\left(\mathrm{k}_{\mathrm{s}}\right)$ by about $25 \%$. This indicates a possible blinding mechanism (clogging occurring on the openings of the geotextile) due to coarse particles being retained by the geotextile pores. The hydraulic gradient in the soil after $100 \mathrm{~s}$ and at the end of static stage (3600 s) remains stable, suggesting that the blinding mechanism occurred during the start of the static stage. For clean sands, which have relatively small amounts of fines available to move through soil pores towards the geotextile, the decrease in permeability of the soil - geotextile zone should be due to either a blinding mechanism (for geotextiles without any significant thickness) or due to clogging (occurring in the pores of geotextiles having significant thickness, where the range of pore sizes is great) (Chang and Nieh, 1996). Fig. 5 shows that only $4 \%$ of the sand particles are smaller than the $\mathrm{O}_{90}$ of the geotextile $(0.070 \mathrm{~mm})$ which suggests that the decrease in permeability of the soil - geotextile zone is due to lodging of sand particles on the geotextile pore openings. Blinding of geotextiles is not expected under high frequency reverse flow conditions since the cyclic flow consecutively clogs and opens the geotextile pores. However, under the dynamic load but unidirectional flow test conditions conducted here, blinding of the geotextile was expected. The GR at the end of the static stage was 1.27 $(<3)$, which suggests that excessive clogging of the geotextile did not occur.

Fig. 6 (a) shows that the hydraulic gradient across soil-geotextile interface slightly increased under cyclic loading, presumably due to further blocking of geotextile openings by the sand particles. However, this increase in the hydraulic gradient was not significant, as shown by the similar values of $\mathrm{k}_{\mathrm{sg}}$ during static and cyclic stages (Fig. 6b). The GR during the cyclic stage increased to 1.51 , which is still less than the recommended limit of 3. The amount of particles collected at the end of the test was insignificant $\left(188 \mathrm{~g} / \mathrm{m}^{2}\right.$; the mass of soil particles per unit area of geotextile), indicating that the migration of sand particles was mostly stopped by the geotextile. 
Results from Test 2 using the PFA are shown in Fig. 7. The water head values during the static stage are nearly the same as the reference or theoretical water head distribution (1:5), indicating similar losses everywhere, with no additional constriction provided by the geotextile (Fig. 7a). The hydraulic gradient of the test sample with depth does not change from $100 \mathrm{~s}$ until the end of the static stage, suggesting that the test sample was stable and the geotextile did not influence flow through the system. This is consistent with the coefficient of permeability $\mathrm{k}_{\mathrm{s}}$ and $\mathrm{k}_{\mathrm{sg}}$ values which do not show a significant change during the static stage (Fig. 7b).

Fig. 7 (a) shows that after $100 \mathrm{~s}$ of cyclic load application, the water head across the soil is more than the theoretical water head based on an assumed constant rate of head loss across the specimen. This is possibly due to densification of soil sample due to the dynamic loading and/ or loss of the fine fraction of soil sample (Hameiri, 2000). The hydraulic gradient of the test sample with depth decreases as the test continues and becomes constant after approximately $4000 \mathrm{~s}$. The difference in hydraulic gradient across the soil - geotextile interface $\left(\mathrm{h}_{\mathrm{g}-25} / \mathrm{Lg}_{\mathrm{g}-25}=2.5\right)$ and within the soil alone $\left(\mathrm{h}_{25-75} / \mathrm{L}_{25-75}=3\right)$ after 4000s is presumably due to the internal migration of fines in the soil (Fig. 7a). The gradation of PFA shows that $85 \%$ of particles (see Fig. 5) are smaller than the $\mathrm{O}_{90}$ of the geotextile $(0.70 \mathrm{~mm})$, hence piping of soil particles through geotextile pores is expected. It can be seen from Fig. 7a that the hydraulic gradient across the soil-geotextile interface decreases under cyclic loading which suggests migration of particles through the geotextile. The permeability $\mathrm{k}_{\mathrm{sg}}$ is slightly higher than $\mathrm{k}_{\mathrm{s}}$ during cyclic loading implying that the soil-geotextile interface is more permeable than the soil alone (Fig. 7b).

A limitation of the new test apparatus is that the weight of soil particles passing through the geotextile is only measured at the end of test (including static and dynamic loading). It is possible that some soil particles are left in the bottom pedestal grooves which are washed into the bottom tank at the end of test. The hydraulic gradient and permeability data for tests 1 and 2 showed that the test samples were stable during the static stage. It was the cyclic loading which enhanced the blinding mechanism (Test 1) and caused migration of soil particles through the geotextile (Test 2). The amount of particles collected at the end of Test 2 was $450 \mathrm{~g} / \mathrm{m}^{2}$. This is 2.4 times more than the particles collected in Test 1 , however it is well below the piping limit of $2500 \mathrm{~g} / \mathrm{m}^{2}$ set by Lafleur et al. (1989); note however that their suggestion was based on long term static filtration tests which were performed for 3000-8000 mins.

\section{APPLICABILITY OF NEW GR TEST APPARATUS}

The dynamic GR test apparatus can be used to find the filtration compatibility of coarse and fine grained soils with geotextiles under static and dynamic conditions. The apparatus is capable of saturating the soil and has complete control over the stresses. The accuracy of pore pressure measurement was improved by using electronic pressure transducers instead of piezometers. The test apparatus is only able to perform filtration tests under static and dynamic unidirectional flow conditions. Such conditions exist underneath highways and railroads as a result of traffic and construction works. The new apparatus allows the tracking of the hydraulic gradient continuously, permitting observations of clogging, flushing of fines, breakdown of natural filter layers, etc.

There are fewer retention criteria available for geotextiles under dynamic flow conditions and these are mostly based on theoretical work. These criteria do not take into account 
the internal stability of soils. Unstable soils may exist in roadway bases adjacent to pavement edge drain (Holtz et al., 2008). The geotextile manufacturing is a very rapidly developing industry and it is possibility that new geotextile products will be available in the near future which may have better filtration performances as compared to the currently available geotextiles. It is recommended that the test equipment should be used to evaluate the filtration compatibility of these geotextiles with soils that have unstable grading.

\section{CONCLUSIONS}

A flexible wall gradient ratio test apparatus was designed and developed for investigating the filtration compatibility of soil-geotextile combinations under dynamic loading conditions. The new test apparatus was designed to reproduce the stress and loading conditions experienced beneath highways and railways. Results from two tests were presented using the same non-woven geotextile: one with sand and the other with a predominately silt soil. Tests involved unidirectional flow with a stage of static load followed by dynamic loading. The following conclusions can be drawn from the work presented in the paper:

1) The new gradient ratio apparatus is applicable to fine grained soils, it enables sample saturation, allows control of confining stresses applied to samples, and achieves a high level of accuracy of pore pressure measurement using electronic pressure transducers.

2) The apparatus is suitable for investigating the combined effects of water flow under cyclic loading on permeability, clogging within the geotextile filter, filter cake formation (on the upstream side of the geotextile), and solids migration through the geotextile.

3) The Gradient Ratios and the equilibrium permeabilities at the end of static and dynamic stages were comparable, implying that the effect of dynamic loading on the filtration mechanism at the soil-geotextile interfaces was of low significance for the tested soil-geotextile combinations presented here. Further research is required to obtain a better understanding of the filtration mechanism for internally unstable soils where fine particles can easily move within the coarse particles until they arrive at the geotextile. 


\section{NOTATION}

Basic SI units given in parenthesis

A Cross-sectional area of test sample

$\mathrm{Cu}$ Coefficient of uniformity

DPT Differential pressure transducer

EOS Equivalent Opening Size

GR Gradient ratio

$\mathrm{h}_{25-75}$ Differential water head within the soil (25-75mm from top of geotextile)

$\mathrm{h}_{\mathrm{g}-25}$ Differential water head across soil - geotextile interface (below geotextile to $25 \mathrm{~mm}$ up in soil)

$\mathrm{i}_{\mathrm{s}} \quad$ Hydraulic gradient within the soil

$i_{s g} \quad$ Hydraulic gradient across soil - geotextile interface

$\mathrm{k}_{\mathrm{s}} \quad$ Permeability of soil

$\mathrm{k}_{\mathrm{sg}} \quad$ Permeability of soil-geotextile interface

L length of the test sample

$\mathrm{O}_{90} \quad$ Characteristic pore size of geotextile ( $90 \%$ pores finer) based on wet sieving

PFA Pulverised fuel ash

Q Volumetric flow rate 


\section{REFERENCES}

1. Alobaidi, I., and Hoare, D. J. (1996). The development of pore water pressure at the subgrade-subbase interface of a highway pavement and its effect on pumping of fines. Geotextiles and Geomembranes, 14, 111-135.

2. Arulrajah, A., Abdullah, A., Bo, M. W., and Leong, M. (2015). Geosynthetic applications in high-speed railways: a case study. Proceedings of the Institution of Civil Engineers - Ground Improvement, 168(1), 3-13.

3. ASTM D5084-16a (2016). Standard Test Methods for Measurement of Hydraulic Conductivity of Saturated Porous Materials Using a Flexible Wall Permeameter, ASTM International, West Conshohocken, PA, USA

4. ASTM D5101-12 (2017). Standard Test Method for Measuring the Filtration Compatibility of Soil-Geotextile Systems, ASTM International, West Conshohocken, PA, USA

5. ASTM D5567-94 (2011). Standard Test Method for Hydraulic Conductivity Ratio Testing of Soil/ Geotextile Systems, ASTM International, West Conshohocken, PA, USA

6. Aydilek, AH, and Edil, TB. (2003). Long-term filtration performance of nonwoven geotextile-sludge systems. Geosynthetics International, 10, 110-123.

7. Bailey, T. D., Harney, M. D., and Holtz, R. D. (2008). Rapid assessment of geotextile clogging potential using the flexible wall gradient ratio test. Geosynthetic Research and Development in Progress. doi:10.1061/40782(161)1

8. Bell, A. L., McCullough, L. M., and Snaith, M. S. (1982). An experimental investigation of sub-base protection using geotextiles. Proceedings of the 2nd International Conference on Geotextiles, Las Vegas, Navada, 2, 435-440.

9. Black, D. K. and Lee, K. L. (1973). Saturating laboratory samples by back-pressure. Journal of Soil Mechanics and Foundation Division, ASCE, 99, No. SM1, 75-93.

10. British Standard 5930. (2015). Code of practice for site investigations. British Standards Institution, London

11. BS EN ISO 12956: 2010. Geotextiles and geotextile-related products. Determination of the characteristic opening size.

12. Carroll, R.G. (1983). Geotextile Filter Criteria, Transportation Research Record, 916, 46-53.

13. Chang, D. T.T. and Nieh, Y.C. (1996) "Significance of gradient ratio test for determining clogging potential of geotextile," Recent developments in geotextile filters and prefabricated drainage geocomposites, ASTM STP 1281, Shobha K. Bhatia and L. David suits, Eds. American Society for Testing and Materials, 113131.

14. Chang, D. T.-T, Li, N.-H, Chen, B.-L, and Fu, H.-M. (2004). Modified Gradient Ratio (GR) Test System with Micro Pore Pressure Transducer Measurement. Chinese J. Geot. Eng., 26 (6), 832-837.

15. Chen, Q., Hanandeh, S., Abu-Farsakh, M. and Mohammad, L. (2017). Performance evaluation of full-scale geosynthetic reinforced flexible pavement. Geosynthetics International, 25(1), 26-36.

16. Daniel, D., Foreman, D., Trautwein, S., and Boynton, S. (1984). Permeability testing with flexible-wall permeameters. Geotechnical Testing Journal, 7 (3), 113122. 
17. Fannin, R. J., and Pishe, R. (2001). Testing and specifications for geotextile filters in cyclic flow applications. Proceedings of the Geosynthetics Conference, Portland, Oregon, USA, February 12 - 14, pp. 423-435.

18. Fannin, R. J., Vaid, Y. P., and Shi, Y. C. (1994). A Critical-Evaluation of the Gradient Ratio Test. Geotechnical Testing Journal, 17(1), 35-42.

19. Fatahi, B., Khabbaz, H., and Ho, L. H. (2011). Effects of geotextiles on drainage performance of ballasted rail tracks. Australian Geomechanics, 46(4), 91-102.

20. Fischer, G. R. (1994). The Influence of Fabric Pore Structure on the Behavior of Geotextile Filters, PhD Dissertation, University of Washington, Seattle, Washington, USA.

21. Fischer, G. R., Maré, A. D., and Holtz, R. D. (1999). Influence of procedural variables on the gradient ratio test. ASTM, GTJODJ, 22(3), 22-31.

22. Giroud, J. P. (1996). Granular filters and geotextile filters. Proceedings of the $2^{\text {nd }}$ International Conference Geofilters, Montreal, Canada, 29-31 May, 565-680.

23. Giroud, J. P. (2010). Development of criteria for geotextile and granular filters. Proceedings of the 9th International Conference on Geosynthetics, Guaruja, Brazil, 1, 45-64.

24. Grand View Research (2016). Geotextile Market Projected To Reach $\$ 8.18$ Billion By 2024. Retrieved from https://www.grandviewresearch.com/pressrelease/global-geotextiles-market

25. Haliburton, T. A., and Wood, P. D. (1982). Evaluation of U.S. Army Corps of Engineers gradient ratio test for geotextile performance. 2nd Int. Conf. on Geotextiles, Las Vegas, Nev., 1, 97-101.

26. Hameiri, A. (2000). Soil / geotextile filtration behavior under dynamic conditions of cyclic flow and vibration. PhD Dissertation, The University of British Columbia.

27. Harney, M. D., and Holtz, R. D. (2001). A flexible wall gradient ratio test. Geosynthetics Conference 2001, Portland, Oregon, 409-422.

28. Hawley, R. A. (2001). Filtration performance of geotextiles in cyclic flow conditions: a laboratory study. MSc Thesis. Retrieved from https://open.library.ubc.ca/collections/831/items/1.0063728

29. Hoare, D. J. (1982). A laboratory study into clay through geotextiles under dynamic loading. Proceedings of the 2nd International Conference on Geotextiles, Las Vegas, 2, 423-428.

30. Holtz, R. D., Christopher, B. R., and Berg, R. R. (2008). Geosynthetic design and construction guidelines. FHWA NHI-07-092, 592 pgs.

31. Hong Y.S., Wu C.S. (2011). Filtration behaviour of soil-nonwoven geotextile combinations subjected to various loads. Geotextiles and Geomembranes, 29, 102115 .

32. Huang, Y.H. (1993). Pavement Analysis and Design. University of Kentucky. Prentice Hall, New Jersey, USA.

33. Hyde, A.F.L., Yasuhara, K., Hirao, K. (1993). Stability criteria for marine clay under one-way cyclic loading. Journal of Geotechnical Engineering, ASCE, 119 , $1771-1789$

34. Indraratna, B., and Nimbalkar, S. (2013). Stress-strain degradation response of railway ballast stabilized with geosynthetics. Journal of Geotechnical and Geoenvironmental Engineering, 139(5), 684-700. 
35. Kermani, B., Xiao, M., Stoffels, S. M., Qiu, T. (2018). Reduction of subgrade fines migration into subbase of flexible pavement using geotextile. Geotextiles and Geomembranes, 46(4), 377-383.

36. Kutay, M. E., and Aydilek, A. (2005). Filtration Performance of Two-Layer Geotextile Systems. ASTM geotechnical testing journal, 28(1), 79-91.

37. Lafleur, J., Mlynarek, J., and Rollin, A. L. (1989). Filtration of Broadly Graded Cohesionless Soils. Journal of Geotechnical Engineering, 115(12), 1747-1768.

38. Lee, S., and Bourdeau, P. L. (2006). Filter performance and design for highway drains. FHWA/IN/JTRP-2005/1, Purdue Univeristy, West Lafayette, Indiana.

39. Matziaris, V., Marshall, A. M., and Yu, H. S. (2015). Centrifuge model tests of rainfall-induced landslides. Recent Advances in Modeling Landslides and Debris Flows: Springer, 73-83.

40. Mohamed, A. M. O., \& Paleologos, E. K. (2017). Fundamentals of Geoenvironmental Engineering: Understanding Soil, Water, and Pollutant Interaction and Transport. Butterworth-Heinemann.

41. Moraci, N. (2010). Geotextile filter: Design, characterization and factors affecting clogging and blinding limit states. In Proceedings of the 9th International Conference on Geosynthetics, Guarujá, Brazil, 23-27 May, 413-435.

42. Moraci, N., and Mandaglio, M.C. 2008. The design of geotextile filters for granular soils. In: Proceedings of The First Pan American Geosynthetics Conference \& Exhibition, Cancun, Mexico, 2-5 March, 477-486.

43. Moraci, N., Mandaglio, M., Ielo, D. (2012). A new theoretical method to evaluate the internal stability of granular soils. Canadian Geotechnical Journal, 49, 45-58.

44. Palmeira, E.M., Trejos Galvis, H.L. (2017). Opening sizes and filtration behavior of nonwoven geotextiles under confined and partial clogging conditions. Geosynthetics International, 24(2), 125-138

45. Palmeira, E. M., Gardoni, M. G., and Bessa da Luz, D. W. (2005). Soil-geotextile filter interaction under high stress levels in the gradient ratio test. Geosynthetics International, 12(4), 162-175.

46. Rollin, A. L., and Lombard, G. (1988). Mechanisms affecting the long term behavior of geotextiles. Geotextiles and Geomembranes, 7(1), 119-145.

47. Shan, H.-Y., Wang, W.-L., and Chou, T.-C. (2001). Effect of boundary conditions on the hydraulic behavior of geotextile filtration system. Geotextiles and Geomembranes, 19(8), 509-527.

48. Skempton, A. W. (1954). The pore-pressure coefficients A and B, Geotechnique, 4, 143-147, 1954

49. U.S. Army Corps of Engineers. (1977). Plastic fiber cloth. Civil Works Construction Guide Specification No. CE-02215, Office Chief of Engineers, Washington, 16.

50. Veylon, G., Stoltz, G., Mériaux, P., Faure, Y.-H., and Touze-Foltz, N. (2016). Performance of geotextile filters after 18 years' service in drainage trenches. Geotextiles and Geomembranes, 44(4), 515-533.

51. Williams, N. D., and Abouzakhm, M. A. (1989). Evaluation of geotextile/soil filtration characteristics using the hydraulic conductivity ratio analysis. Geotextiles and Geomembranes, 8(1), 1-26. 


\section{FIGURES}

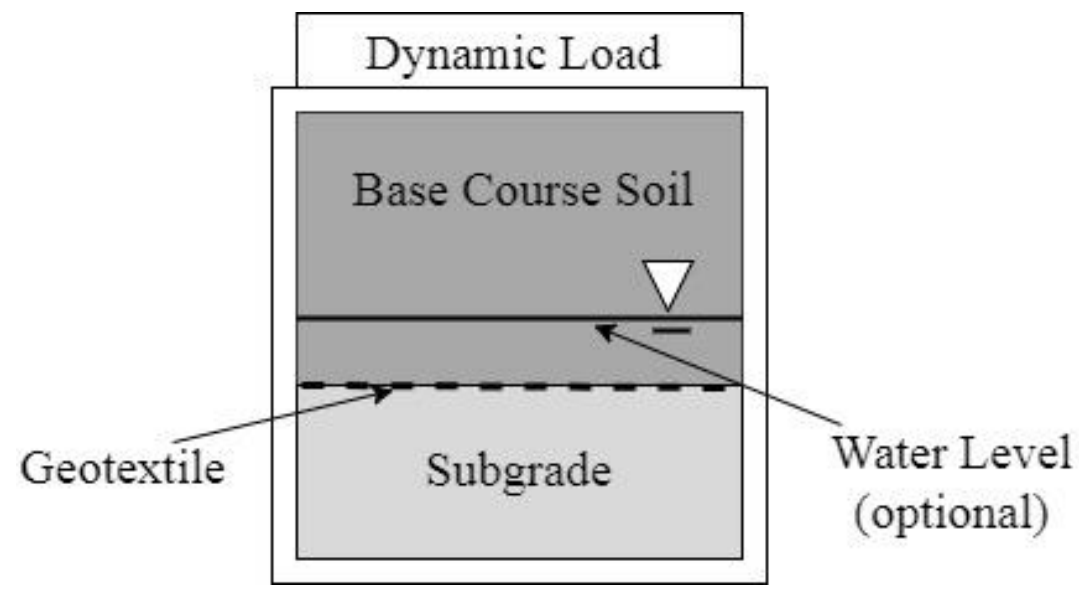

Fig. 1 Dynamic test setup (after Glynn and Cochrane, 1987)

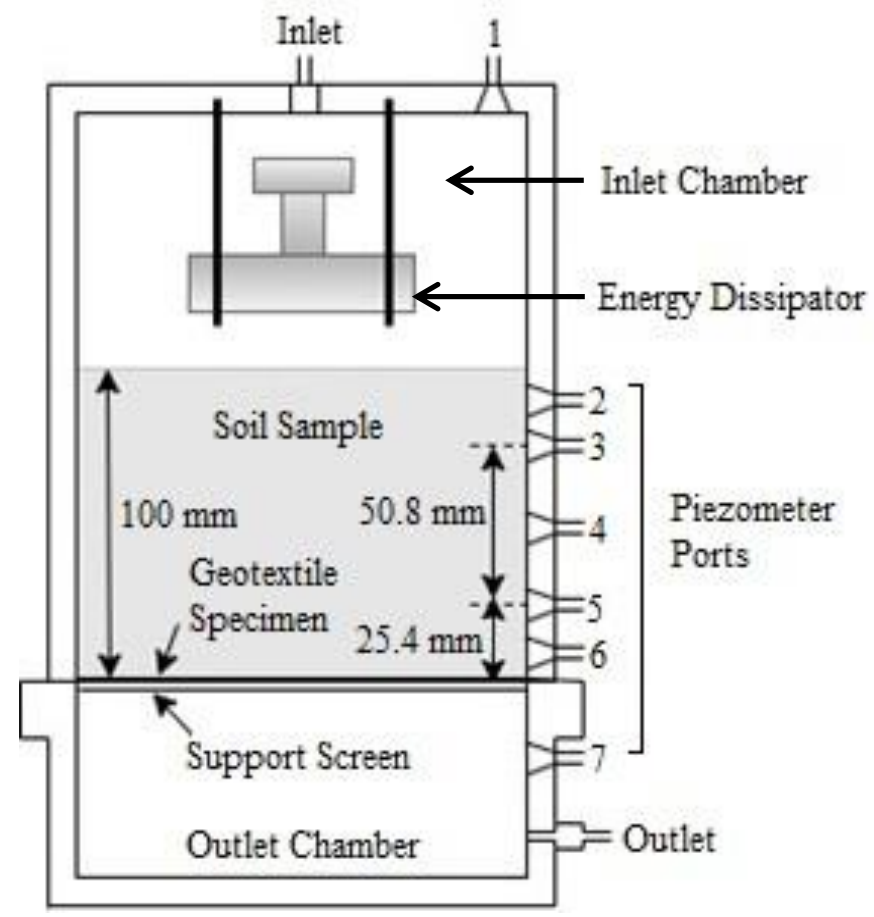

Fig. 2 Traditional GR test arrangement (after Fannin et al., 1994) 


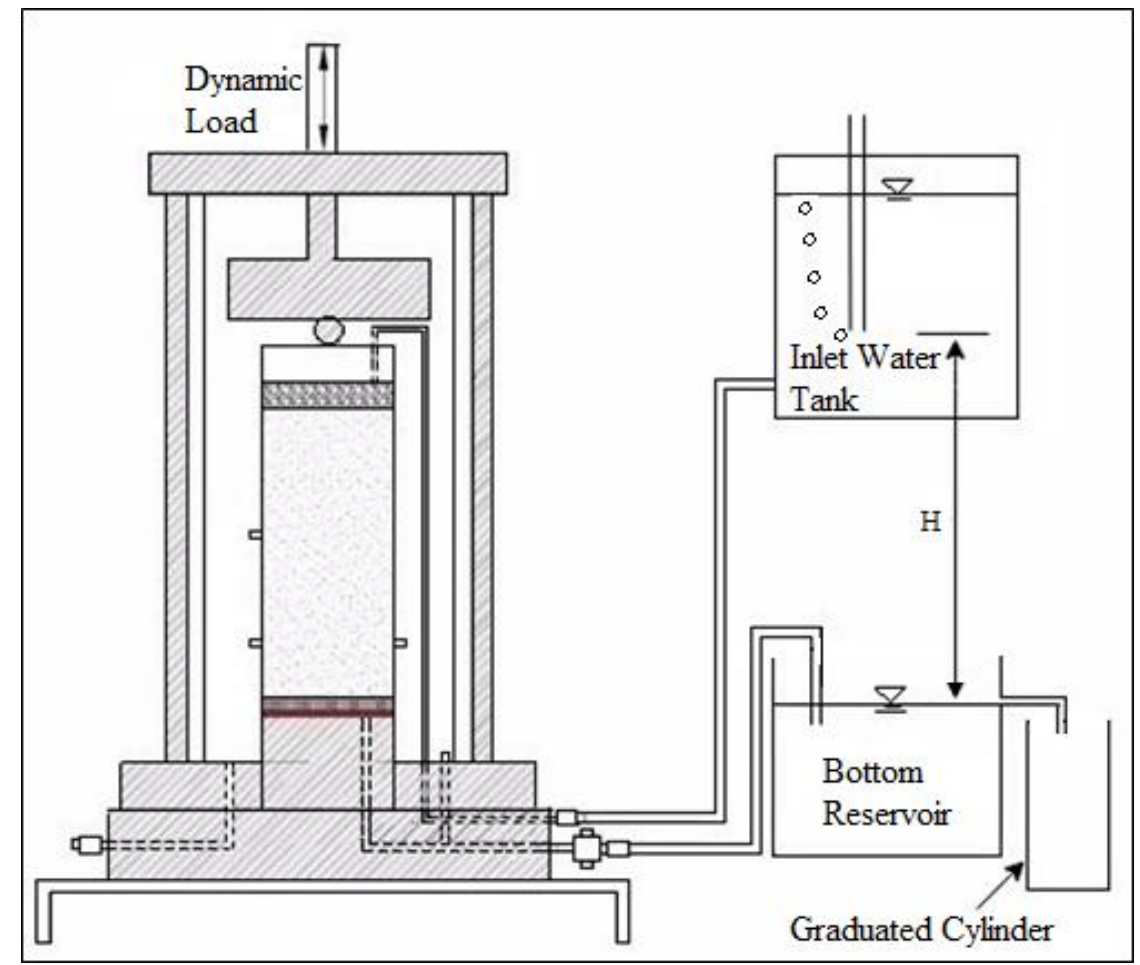

Fig. 3 Dynamic GR apparatus layout
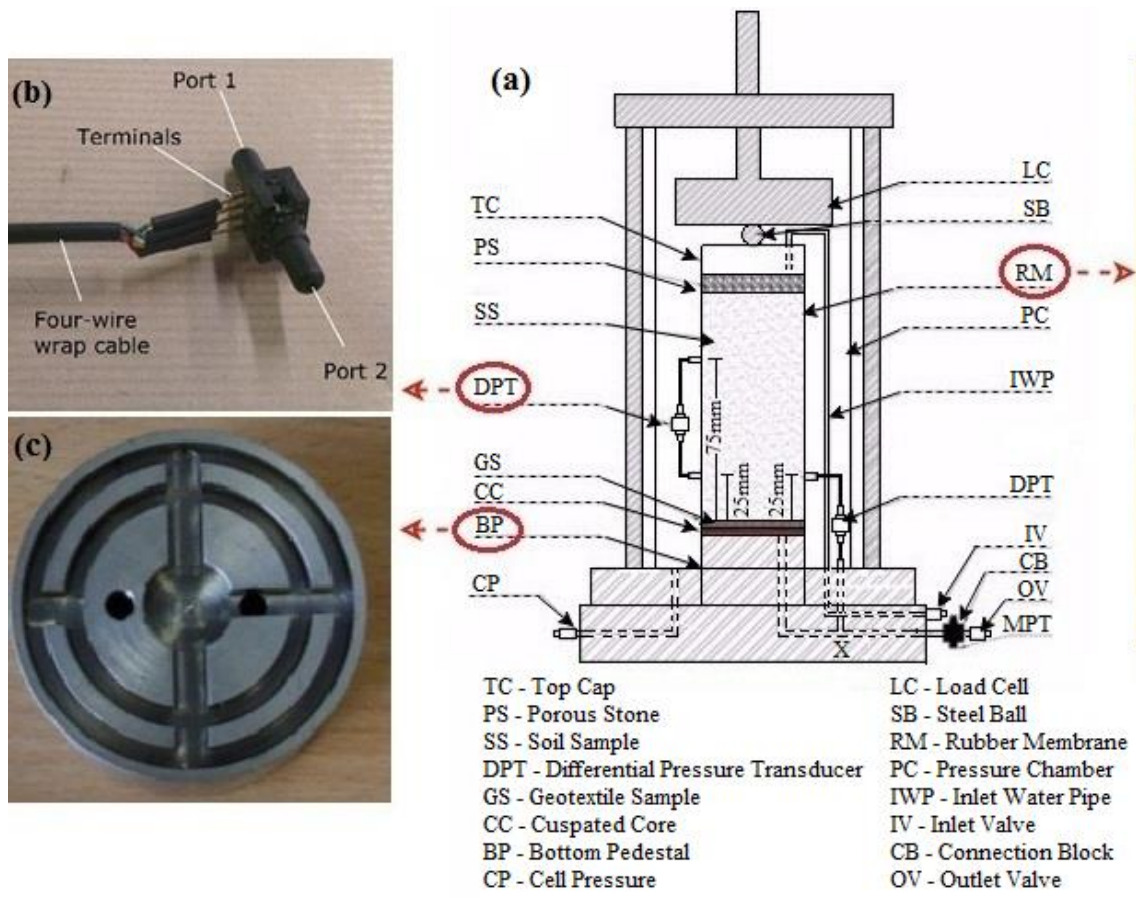

Fig. 4 (a) Modified triaxial cell; (b) differential pressure transducers (DPT); (c) bottom pedestal; and (d) connection detail of DPT pipes and rubber membrane 


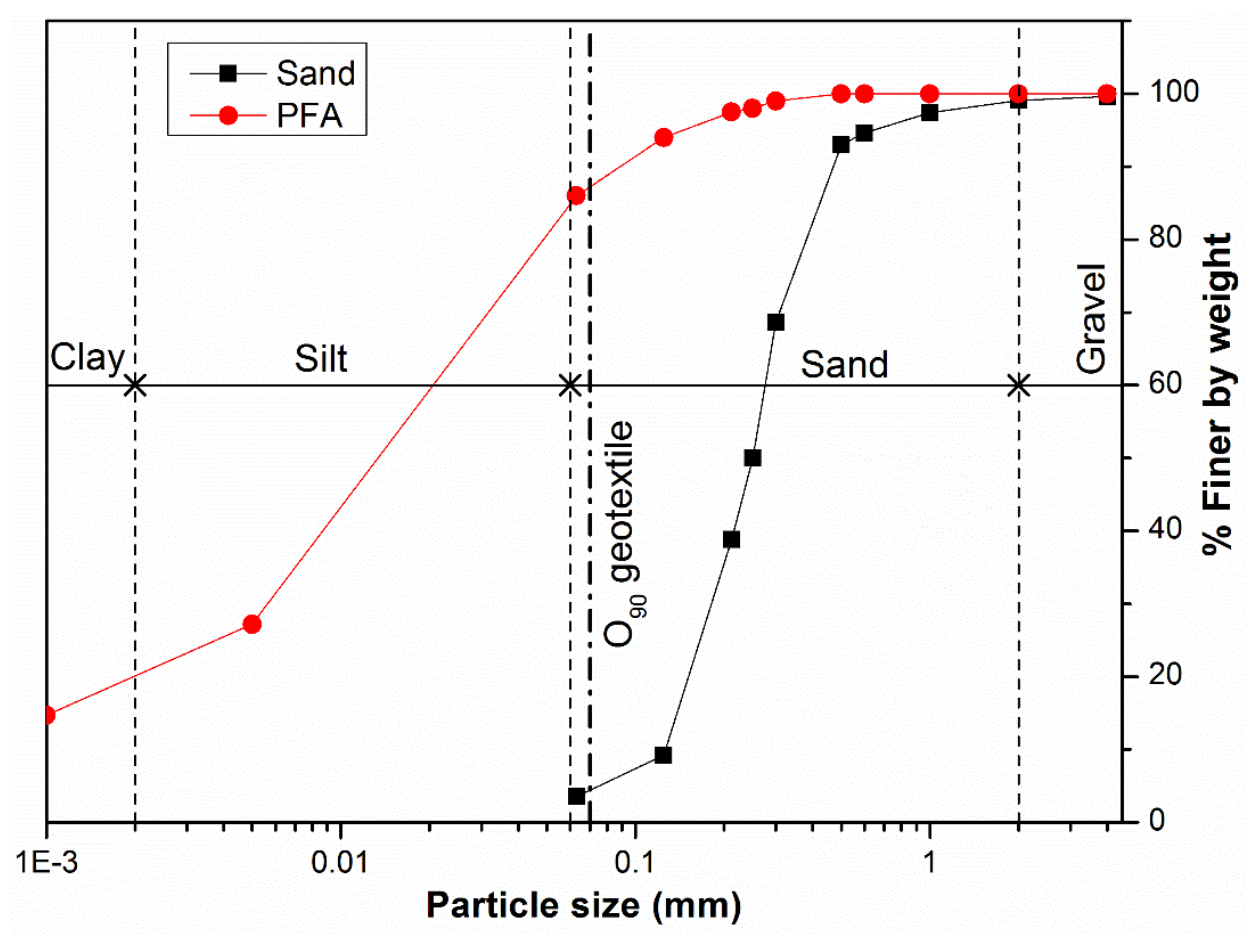

Fig. 5 Gradations of sand and PFA 

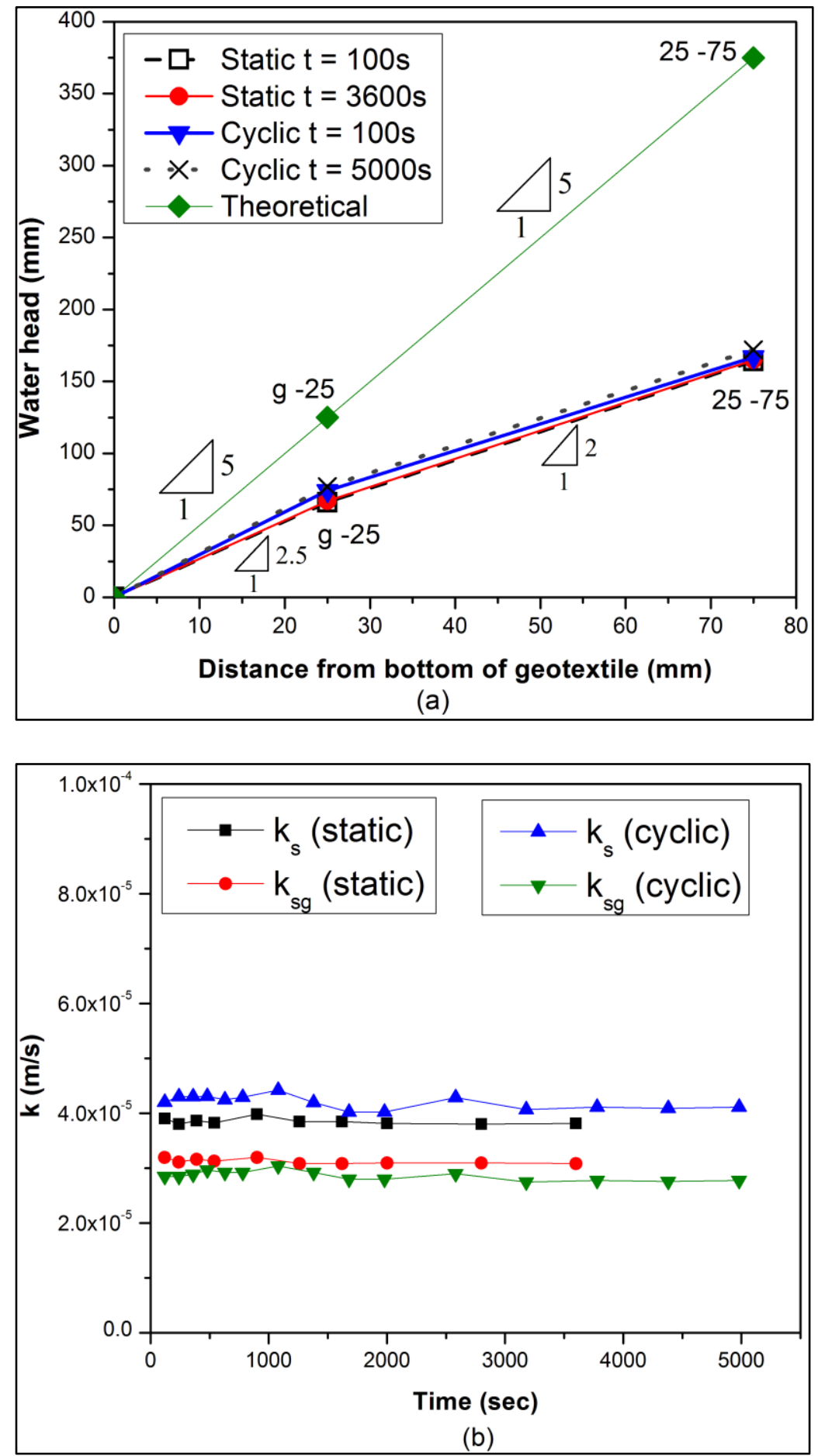

Fig. 6 Test 1 - (a) water head distribution along sand sample; and (b) permeability variation with time 

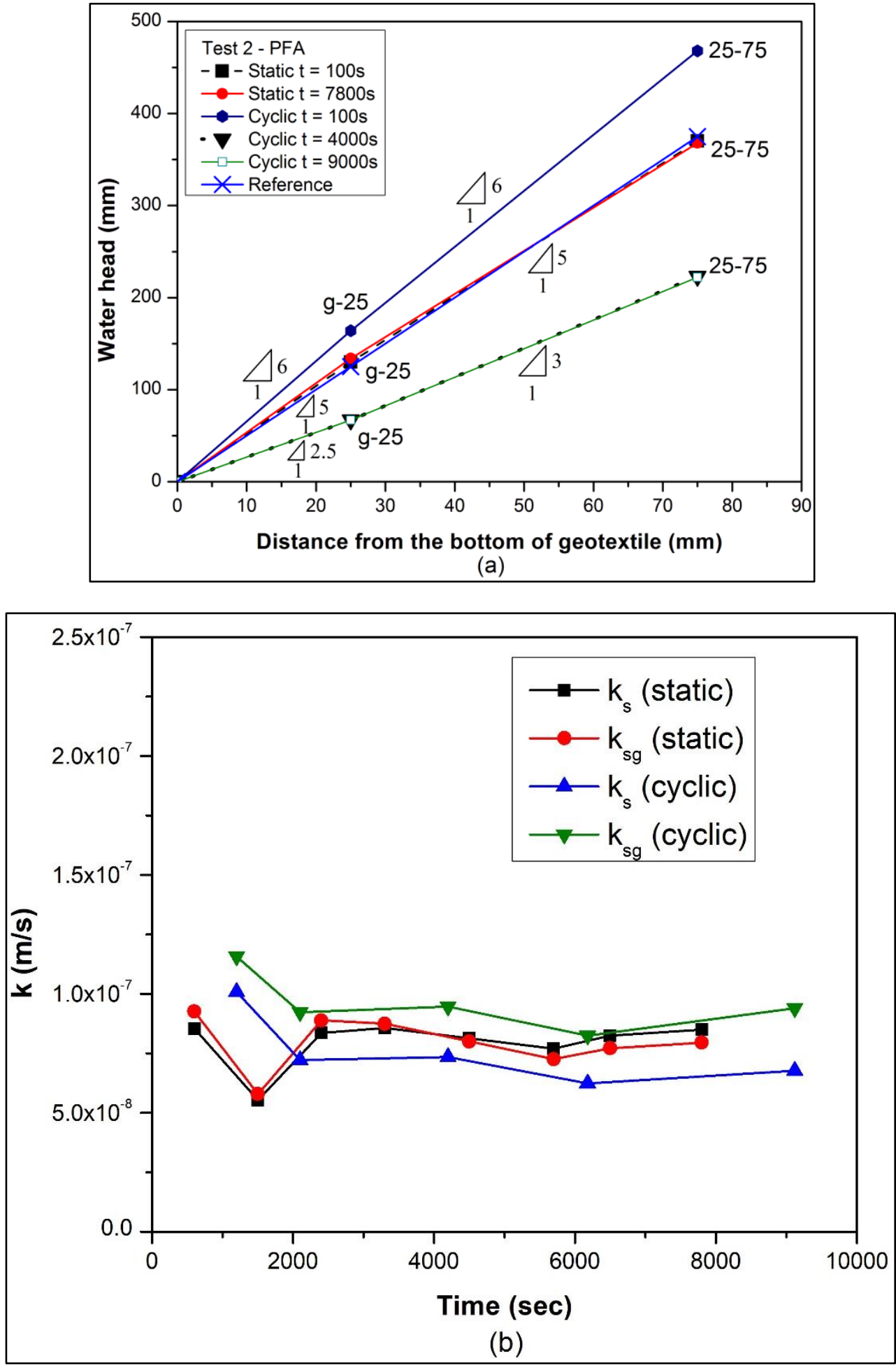

Fig. 7 Test 2 - (a) water head distribution along PFA sample; and (b) permeability variation with time 
Table 1 Physical Properties of the soil materials

\begin{tabular}{lllllll}
\hline Soil & $\mathrm{D}_{85}$ & $\mathrm{D}_{50}$ & $\mathrm{D}_{15}$ & $\mathrm{C}_{\mathbf{u}}$ & $\begin{array}{l}\text { Maximum } \\
\text { Dry } \\
\text { Density } \\
\mathrm{kg} / \mathrm{m}^{3}\end{array}$ & $\begin{array}{l}\text { Optimum } \\
\text { Moisture } \\
\text { Content } \\
\%\end{array}$ \\
\hline Sand (Test 1) & 0.420 & 0.250 & 0.150 & 1.9 & 1936 & 12 \\
PFA (Test 2) & 0.063 & 0.015 & 0.001 & 38.3 & 1436 & 27.5 \\
\hline
\end{tabular}

$\mathrm{D}_{\mathrm{i}}$ : Indicative Grain Size ; $\mathrm{C}_{\mathrm{u}}$ : Coefficient of Uniformity $\left(\mathrm{D}_{60} / \mathrm{D}_{10}\right)$ 